\title{
The Impact of Work Stress on Employee Job Satisfaction with the Moderating Effect of Social Support in Public and Private Sector Organization. (Empirical Evidence from Pakistani Organizations)
}

\author{
Muhammad Hasnain Ali \\ MS Business Administration \\ Bahauddin Zakariya University Multan, Pakistan \\ Mohsin Shahzad \\ MS Business Administration \\ Bahauddin Zakariya University Multan, Pakistan \\ Kaleem Ullah Malik \\ MS Business Administration \\ Bahauddin Zakariya University Multan, Pakistan
}

\begin{abstract}
This study is causal to investigate the effect of job stress on employee's job satisfaction with the moderating effect of social support. In Job stress, two dimensions are analyzed first is work-life balance and second is work place anxiety. Primary data were collected through the questionnaire from 500 employees of public and private sector organizations. Data was collected from only those organizations that are listed with SECP (Security and Exchange Corporation of Pakistan) as well as listed in stock exchange. This study proved a negative relationship between Work-life balances on employee job satisfaction. Moreover, there has been also a negative relationship between work place anxiety on the employee job satisfaction perform. Social support decreases the negative relationship between work-life balance and employee job satisfaction. In addition to that, its effect is also positive in the negative relationship between work anxieties on employee's job performance. This study is helpful for the top managerial policy makers to improve the employee's satisfaction level by incorporating job stress management and also by providing the social support.
\end{abstract}

Keywords: Work-Life balance,, Work-Place Anxiety, Social Support, Employee job satisfaction

DOI: $10.7176 / \mathrm{RHSS} / 9-1-10$

\section{Introduction}

Human stress is used to describe the body's responses to demands place on it, whether these demands are favorable or unfavorable. Job stress is one of the most important workplace health risks for employees in developed and developing countries. There are many of workplace factors, called job stressors that make jobs stressful and difficult for number of employees in services as well as manufacturing industries. Additional stressors relate Interpersonal relationships at work such as conflicts with the behavior of supervisor's conflicts with colleagues, conflicts with juniors and conflicts with management rules. Job satisfaction has been the most frequently investigated variable in organizational behavior. Work is a central part of almost everyone's life. Work and the workplace emphasizes many issues related to organizational psychology including job satisfaction, quality of work life, human factors, physical environment, performance appraisal, motivation and leadership, and the physical and mental health of workers. As per side the job satisfaction is an achievement indicator in career developmental tasks. Employee Job satisfaction means how much employees feel positive about their job and the different of their jobs. Low job satisfaction can be a major indicator of decrease in employee production and can result in behavior such as absenteeism and turnover intentions. According to medically stress is also harmful for stomach and reduces overall efficiency of human. Bali, A. (2015). Job stress result from non-fulfillment of needs; continued stresses create anxieties, and anxiety leads to tension. The residual effect of tension is felt, monitored and evaluated both physiologically and psychologically and is ultimately linked with psychosomatic disorders. Heart Association policy statements highlight psychosocial stress as a potential barrier to healthy lifestyles and optimal medication adherence, and recommend management of stress in individuals with high cardiovascular risk and also normotensive,non-obese, physically active, had normal blood cholesterol, established cardiovascular diseases, but also that harmful effects of stress attributable to the lifestyle risk factors measured or poor adherence to pharmacotherapy; excess mortality risk was observed even among patients successfully treated for cardio metabolic diseases. There are various ways of expanding standard care to address work stress in patients, including systematic screening for stress and, if needed, interventions such as consultation, rehabilitation, job redesign, reductions in working hours, an on health grounds.6,7 In a Cochrane review of 35 randomized controlled trials a total of 10703 patients with coronary heart disease who had at least 6 
months' follow-up, psychological interventions that alleviated stress of their work( Kivimäki, M., Pentti, J., Ferrie, J. E., Batty, G. D., Nyberg, S. T., Jokela, M., ... \& Goldberg, M. (2018).

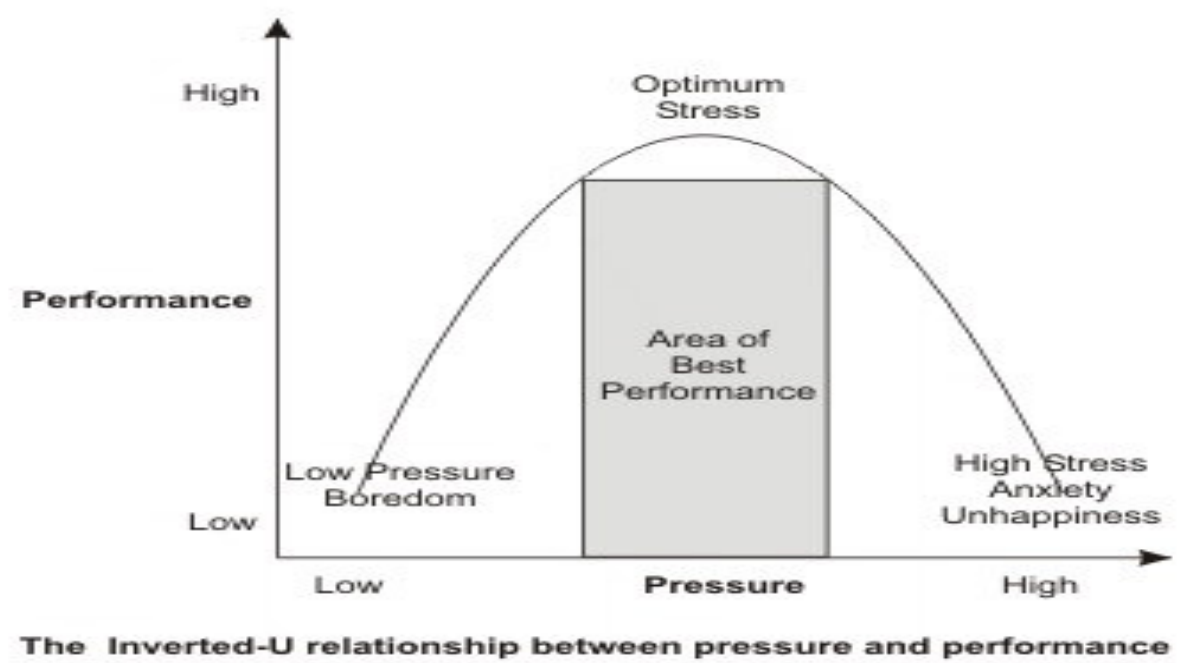

Source :Bali, A. (2015). Psychological factors affecting sports performance. International Journal of Physical Education, Sports and Health, 1(6), 92-95.

Although in the previous studies, relationship between job stress and job satisfaction has been analyzed but in the current study we have analyzed this relation in different scenario. Generally speaking, stress and anxiety are simply biological and physiological reactions to perceived threats to safety or external danger. Once the stressful situation has passed or the 'stressor' is removed, these feelings should subside. Anxiety is a common concern in today's, world. While anxiety and stress are natural, inevitable experiences in life, there are times where it can take a severe toll on the state of mental health and quality of life as well as employee job satisfaction.Workplace anxiety is a learnt response to stress and can be triggered from a range of factors, with some cases more severe and debilitating than others. While most people experience some levels of stress in the workplace, workplace anxiety differs in that it goes beyond the body's natural response. Work place Anxiety might be many reasons But in our study its investigate that either due to social support it's reduces and its effects on employee job satisfaction

\section{Literature Review: \\ Definition of variables: \\ Work Life balance}

According to Kalliath, T., \& Brough, P. (2008)."Work-life balance is the individual perception that work and non-work activities are compatible and promote growth in accordance with an individual's current life priorities". Work-life balance is an important aspect of a healthy work environment. Maintaining work-life balance helps reduce stress and helps prevent burnout in the workplace.

\section{Work place Anxiety}

According to Muschalla, B., \& Linden, M. (2014) define Work place anxiety in following words "A certain amount of stress and anxiety is normal at work as well as at home. However, persistent, excessive, and irrational anxiety that interferes with everyday functioning is often an indication of an anxiety disorder"

\section{Social Support}

According to Racino, J. (2006)."Social support is the perception and actuality that one is cared for, has assistance available from other people, and most popularly, that one is part of a supportive social network. These supportive resources can be emotional (e.g., nurturance), tangible (e.g., financial assistance), informational (e.g., advice), or companionship (e.g., sense of belonging) and intangible (e.g., personal advice)"

\section{Employee Job Satisfaction}

The concept of job satisfaction has been defined in many ways. However, the most-used Definition of job satisfaction in organizational research is that of Locke (1976), who described job satisfaction as "a pleasurable or positive emotional state resulting from the apprajsal of one's job or job experiences".

According to Thompson, E. R., \& Phua, F. T. (2012)." Employee job satisfaction is a measure of workers' contentedness with their job, whether or not they like the job or individual aspects or facets of jobs, such as 
nature of work or supervision"

According to Haar, J. M., Russo, M., Suñe, A., \& Ollier-Malaterre, A. (2014) investigates work life balance positively related to job and life satisfaction and negatively related to anxiety and depression across the various cultures.. High levels of work life balance were more positively associated with job and life satisfaction for employees High levels of work life balance were more positively associated with job and life satisfaction and more negatively associated with anxiety for individuals in gender egalitarian society also. Overall, strong support for work-life balance from being beneficial for employees. According to Bowen, P., Edwards, P., Lingard, H., \& Cattell, K. (2014) Occupational stress affects the health and wellbeing of employees who work, and the relationship between job demands, job control, workplace support, and experiences of stress Predictors displaying a significant relationship with occupational stress are the presence of work-life imbalance, the need to 'prove' oneself, hours worked per week, working to tight deadlines, and support from line managers in difficult situations at work positively affect the employee job satisfaction. The Organizations should look to improving managerial and collegial support for professionals and industry must give attention to how the need to work long hours is justified. This study explores display a common pattern of behavior when implementing work life balance policies. The benefits of implementing work life balance policies improve conditions for the workers themselves or improve the firm's productivity work life balance policies. Performance makes the implementation of work life balance policies more attractive to human resources managers( Adame-Sánchez, C., GonzálezCruz, T. F., \& Martínez-Fuentes, C. (2016).According to Allisey, A. F., Noblet, A. J., Lamontagne, A. D., \& Houdmont, J. (2014) investigates that work job stress and employee job satisfaction, these relationships were either reduced, or no longer significant. Task-oriented conditions were more strongly associated with job stress while relational or socially oriented conditions were stronger predictors of job satisfaction. Monitoring stress and satisfaction may be a valuable component of employees retention efforts, and could offer early-warning of impending turnover among staff and enhances employees job satisfaction. Stress is in a meaningful correlation with job stress, job satisfaction and job motivation. results of the essay defined motivation. Also stress is in a meaningful correlation with job stress, job satisfaction and job motivation. Results of the essay defined motivation (Khalatbari, J., Ghorbanshiroudi, S., \& Firouzbakhsh, M. (2013). According to Ling, A. W., Bahron, A., \& Boroh, P. (2014) job satisfaction than male employees. This can be explored to enhance the body of knowledge, find out the factors which cause these differences. The management may also need to pay more attention to the climates which could affect the role stress factors, working condition and job satisfaction. Administrative and supervisory support are inversely related to job stress, while job involvement is affected positively by supervisory support and negatively by family/friends support.. Lambert, E. G., Minor, K. I., Wells, J. B., \& Hogan, N. L. (2016).

\section{Research Objectives}

The research objectives of this study as below:

- To know how to reduce the job stress of level of employees through social support

- To determine how job stress effects the employees job satisfaction

- To determine the effect of social support in work life balance and employees job satisfaction

- To know the effect of social support in workplace anxiety and employee job satisfaction.

\section{Research Model}

\section{Work Stress}

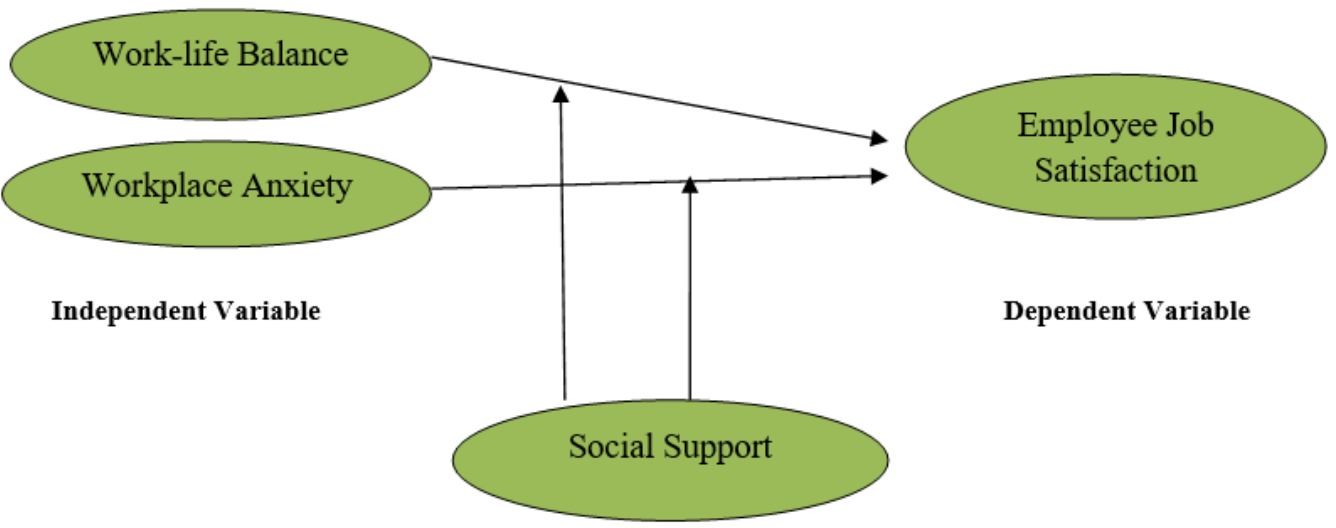

Moderating Variable 


\section{Hypotheses}

H.1 There is a significant relationship between work- life balance and employee job satisfaction.

H.3 There is a significant relationship between work anxiety and employee job satisfaction.

H.2 Social support moderates the relationship between work-life balance and employee job satisfaction.

H.4 Social support moderates the relationship work anxiety and employee job satisfaction.

\section{Research Methodology}

The design of the study was casual. The causal connections between the variables were quantified. Cross sectional data were collected at one point in time. Primary data have been collected through the questionnaires. In this study population was the employees of all the public and private sector organizations of Pakistan. The questionnaire was composed of three sections: First sections described about the research and ensured the respondents about data confidentiality, second section was consisted of instruments for variables of the study and third section was composed of asking general information about the respondents. second section included 44 items in form of Likert scale ranging from 1 to 5 (where 1=Strongly Disagree, 2=Disagree, $3=$ Neutral, $4=$ Agree and 5=strongly Agree) that have been used to collect the data from the target respondents. Questionnaire were got filled through personal visits by the researchers from total 500 respondents including Assistant managers, Managers, Zonal managers, Clerics, terminal directors and Assistant vice president in the public and sector organizations.. Both Probability and Non-Probability sampling techniques were used in this data collection procedure, because of the fact that, in non - probability sampling, the sample could generalize to the population better. Multiple regression technique was used to analyze the data. The developed questionnaire has been pretested with a few Employees to ensure the quality of the questions.

\begin{tabular}{|c|c|c|c|}
\hline Variables & Category & Frequency & Percenta \\
\hline \multirow{4}{*}{ Gender } & Male & 287 & 57.4 \\
\hline & Female & 205 & 41.0 \\
\hline & Others & 8 & 1.60 \\
\hline & Total & 500 & 100 \\
\hline \multirow[t]{6}{*}{ Age } & 20-30 years & 290 & 58.0 \\
\hline & $31-40$ years & 113 & 22.6 \\
\hline & $41-50$ years & 67 & 13.4 \\
\hline & $51-60$ years & 20 & 4.00 \\
\hline & 61 and above years & 10 & 2.00 \\
\hline & Total & 500 & 100 \\
\hline \multirow[t]{6}{*}{ Designation } & Assistant Manager & 168 & 33.6 \\
\hline & Operational Manager & 155 & 31.0 \\
\hline & Manager & 77 & 15.4 \\
\hline & Zonal Manager & 60 & 12.0 \\
\hline & Assistant Vice President & 40 & 8.00 \\
\hline & Total & 500 & 100 \\
\hline \multirow[t]{7}{*}{ Education } & Bachelor & 118 & 23.6 \\
\hline & Master & 187 & 37.4 \\
\hline & MS/MPhil/PhD & 111 & 22.2 \\
\hline & Others & 84 & 16.8 \\
\hline & Total & 500 & 100 \\
\hline & Public & 247 & 49.4 \\
\hline & Private & 203 & 40.6 \\
\hline \multirow{2}{*}{ Organization } & Others & 50 & 10 \\
\hline & Total & 500 & 100 \\
\hline
\end{tabular}




\section{Measurement of variables}

Job stress two dimensions one is work life balance and second is work anxiety for measuring them. All the instruments were adopted from as described in Table.

\begin{tabular}{|l|l|l|}
\hline Serial No. & Variables & Instruments adopted \\
\hline $\mathbf{1}$ & Work life balance & Krymis, E. (2011) \\
$\mathbf{2}$ & Work place anxiety & McCarthy, J. M., Trougakos, J. P., \& Cheng, B. H. (2016) \\
$\mathbf{3}$ & Social support & Umeadi, C. A. (2015) \\
$\mathbf{4}$ & Employee Job Satisfaction & Pang, K., \& Lu, C. S. (2018)
\end{tabular}

\section{Reliability of the instrument}

Crowder, M. J. (2017) described that reliability is a word with many different connotations. When applied to behavior, it usually refers to that person's ability to perform certain tasks according to a specified standard. By extension, the word is applied to a piece of equipment, or a component of a larger system, to mean the ability of that equipment or component to fulfill what is required of it. As used today, however, reliability is almost always a quantitative concept, and this implies the need for methods of measuring reliability. Reliability of the instrument was calculated through the use of SPSS. DeVellis, R. F. (2016) indicated that Alpha value of less than 0.7 is tolerable while the value of 0.7 or above is preferred.

Table No. 1 Reliability Statistics

\begin{tabular}{|l|l|l}
\hline Variables & Cronbach's Alpha & No. of Items
\end{tabular}

$\begin{array}{lll}\text { Work- Life Balance( WLB) } & .857 & 4 \\ \text { Work place Anxiety( WPA) } & .761 & 8 \\ \text { Social Support( SS) } & .840 & 8 \\ \text { Employee job satisfaction ( EJS) } & .740 & 7\end{array}$

\section{Results and Discussion}

Multiple regressions have been applied on the data to determine the causal relationships among independent and dependant variables.

\section{Correlation}

\section{Correlations}

\begin{tabular}{|c|c|c|c|c|c|c|}
\hline & & $\begin{array}{l}\text { Empl_Job_S } \\
\text { at }\end{array}$ & $\begin{array}{l}\text { Work_Life_Bala } \\
\text { nce }\end{array}$ & $\begin{array}{l}\text { Work_Anxie } \\
\text { ty }\end{array}$ & $\begin{array}{l}\text { Social_Supp } \\
\text { ort }\end{array}$ & $\begin{array}{l}\text { Work_Stre } \\
\text { ss }\end{array}$ \\
\hline \multirow{5}{*}{$\begin{array}{l}\text { Empl_Job_Sa } \\
\mathrm{t}\end{array}$} & Pearson & 1 & $-.659^{* *}$ & $-.613^{* *}$ & $.734^{* *}$ & $-.689^{* *}$ \\
\hline & Correlation & & & & & \\
\hline & Sig.(2-tailed) & & .000 & .000 & .000 & .000 \\
\hline & $\mathrm{N}$ & 500 & 500 & 500 & 500 & 500 \\
\hline & $\begin{array}{l}\text { Pearson } \\
\text { Correlation }\end{array}$ & $-.659^{* *}$ & 1 & $.633^{* *}$ & $-.624^{* *}$ & $.832^{* *}$ \\
\hline \multirow[t]{3}{*}{$\begin{array}{l}\text { Work_Life_B } \\
\text { alance }\end{array}$} & $\begin{array}{l}\text { Sig. } \\
\text { tailed) }\end{array}$ & .000 & & .000 & .000 & .000 \\
\hline & $\mathrm{N}$ & 500 & 500 & 500 & 500 & 500 \\
\hline & $\begin{array}{l}\text { Pearson } \\
\text { Correlation }\end{array}$ & $-.613^{* *}$ & $.633^{* *}$ & 1 & $-.663^{* *}$ & $.956^{* *}$ \\
\hline \multirow[t]{3}{*}{$\begin{array}{l}\text { Work_Anxiet } \\
\text { y }\end{array}$} & $\begin{array}{l}\text { Sig. } \\
\text { tailed })\end{array}$ & .000 & .000 & & .000 & .000 \\
\hline & $\mathrm{N}$ & 500 & 500 & 500 & 500 & 500 \\
\hline & $\begin{array}{l}\text { Pearson } \\
\text { Correlation }\end{array}$ & $.734^{* *}$ & $-.624^{* *}$ & $-.663^{* *}$ & 1 & $-.711^{* *}$ \\
\hline \multirow{3}{*}{$\begin{array}{l}\text { Social_Suppo } \\
\mathrm{rt}\end{array}$} & $\begin{array}{l}\text { Sig. } \\
\text { tailed })\end{array}$ & .000 & .000 & .000 & & .000 \\
\hline & $\mathrm{N}$ & 500 & 500 & 500 & 500 & 500 \\
\hline & $\begin{array}{l}\text { Pearson } \\
\text { Correlation }\end{array}$ & $-.689^{* *}$ & $.832^{* *}$ & $.956^{* *}$ & $-.711^{* *}$ & 1 \\
\hline \multirow[t]{2}{*}{ Work_Stress } & $\begin{array}{l}\text { Sig. } \\
\text { tailed })\end{array}$ & .000 & .000 & .000 & .000 & \\
\hline & $\mathrm{N}$ & 500 & 500 & 500 & 500 & 500 \\
\hline
\end{tabular}

**. Correlation is significant at the 0.01 level (2-tailed). 


\section{Table 1.1 Model Summary}

\begin{tabular}{|l|l|l|l|l|}
\hline Model & R & R Square & Adjusted R Square & Std. Error of the Estimate \\
\hline 1 & $.812^{\mathrm{a}}$ & .759 & .753 & 5.53254
\end{tabular}

a. Predictors: (Constant), WLB( Work -Life Balance)

b. Dependent Variable: EJS( Employee Job Satisfaction)

Moore, D. S., Notz, W., \& Fligner, M. A. (2013) described that value of R should between + and -1 . According to Miller, R. L. (2017) described if the value of R Square is greater than .70, That shows a greater effect. In this model summary, the value of R Square is greater than .70 that is .759 shows a strong effect size

Table 1.2

Coefficients $^{\mathrm{a}}$

\begin{tabular}{|c|c|c|c|c|c|c|}
\hline \multirow[t]{2}{*}{ Model } & & \multicolumn{2}{|c|}{ Unstandardized Coefficients } & Standardized & \multirow[t]{2}{*}{$\mathrm{T}$} & \multirow[t]{2}{*}{ Sig. } \\
\hline & & $\mathrm{B}$ & Std. Error & Beta & & \\
\hline \multirow{2}{*}{1} & (Constant) & 35.030 & 1.106 & & 31.677 & .000 \\
\hline & WLB & -1.260 & .071 & -.659 & -17.727 & .000 \\
\hline
\end{tabular}

a. Dependent Variable: EJS( Employee job satisfaction)

The effect of work-life balance on the employee's job satisfaction is highly significant $p=0.00$, While, the $\beta$ value $(-1.260)$ of work-life balance shows a significant negative effect of on the employee's performance.

Table 1.3

Model Summary

\begin{tabular}{|l|l|l|l|l|}
\hline Model & R & R Square & Adjusted R Square & Std. Error of the Estimate \\
\hline 1 & $.813^{\mathrm{a}}$ & .787 & .784 & 4.80930
\end{tabular}

a. Predictors: (Constant), WA

b. Dependent Variable: EJS

In this model summary, the value of $\mathrm{R}^{2}$ is 0.887 while the value of Adjusted $\mathrm{R}^{2}=0.785$ shows that the model better fits the data. It can be established the leaders have a key role to decide about the performance of the employees through the implementation of leadership styles.

\section{Table 1.4}

\section{Coefficients $^{\mathrm{a}}$}

\begin{tabular}{|ll|l|l|l|l|}
\hline \multirow{2}{*}{ Model } & \multicolumn{2}{l|l|}{ Unstandardized Coefficients } & \multicolumn{2}{l|}{$\begin{array}{l}\text { Standardized } \\
\text { Coefficients }\end{array}$} & T \\
\cline { 3 - 5 } & & B & Std. Error & Beta & \\
\hline
\end{tabular}

a. Dependent Variable: EJS

The table revealed that the work anxiety reduces the employee job satisfaction provided with the values $\mathrm{P}$ $=0.000, \beta=-.619$. It denotes the mild negative relation between work anxiety and employee job satisfaction 
Moderating effect of Social Support between Job Stress and Employee job Satisfaction

Individual Effect

Combined Effect

\begin{tabular}{|l|l|l|l|l|}
\hline Model & R & R Square & Adjusted R Square & Std. Error of the Estimate \\
\hline 1 & $.689^{\mathrm{a}}$ & .574 & .673 & 5.33237 \\
2 & $.748^{\mathrm{a}}$ & .559 & .557 & 4.88832 \\
\hline
\end{tabular}
a. Predictors: (Constant), JS
b. Predictors: (Constant), JS, JS_SS
c. Dependent Variable: EJS

\begin{tabular}{|c|c|c|c|c|c|}
\hline Model & Sum of Squares & Df & Mean Square & $\mathrm{F}$ & Sig \\
\hline Regression & 10510.567 & 1 & 10510.567 & 369.645 & $.000^{\mathrm{b}}$ \\
\hline 1 Residual & 11658.023 & 499 & 28.434 & & \\
\hline Total & 22168.590 & 500 & & & \\
\hline Regression & 12395.247 & 2 & 6197.623 & 259.361 & $.000^{\mathrm{c}}$ \\
\hline 2 Residual & 9773.343 & 498 & 23.896 & & \\
\hline Total & 22168.590 & 500 & & & \\
\hline
\end{tabular}
a. Dependent Variable: EJS
b. Predictors: (Constant), JS
c. Predictors: (Constant), JS, JS SS

Coefficient

\begin{tabular}{|c|c|c|c|c|c|}
\hline \multirow[t]{2}{*}{ Model } & \multicolumn{2}{|c|}{ Unstandardized Coefficients } & Standardized Coefficients & \multirow[t]{2}{*}{$\mathrm{T}$} & \multirow[t]{2}{*}{ Sig. } \\
\hline & B & Std. Error & Beta & & \\
\hline \multirow{3}{*}{$\begin{array}{ll}1 & \text { (Constant) } \\
\text { JS } \\
\\
(\text { Constant })\end{array}$} & 38.327 & 1.189 & & 32.234 & .000 \\
\hline & -.498 & .026 & -.689 & -19.226 & .000 \\
\hline & 32.153 & 1.293 & & 24.869 & .000 \\
\hline \multirow{2}{*}{2 JS } & -.546 & .024 & -.755 & -22.416 & .000 \\
\hline & .010 & .001 & .299 & 8.881 & .000 \\
\hline
\end{tabular}

a. Dependent Variable: EJS

\begin{tabular}{|l|r|r|r|r|}
\hline Model & R & R Square & Adjusted R Square & Std. Error of the Estimate \\
\hline 1 & & & & \\
2 & $.613^{\mathrm{a}}$ & .627 & .574 & 5.80930 \\
$.710^{\mathrm{b}}$ & .505 & .502 & 5.18219 \\
\hline
\end{tabular}

a. Predictors: (Constant), Work_Anxiety

In this model value of $\mathrm{R}$ square $=.627, .505$ and the value of adjusted $\mathrm{R}^{2}$ is $(.574, .502)$ that shows strong effect size

On the relationship between variables.

b. Predictors: (Constant), Work_Anxiety, Int_WA_SS

\section{Coefficients $^{\mathrm{a}}$}

\begin{tabular}{|c|c|c|c|c|c|c|c|}
\hline \multirow[t]{2}{*}{ Model } & & \multicolumn{2}{|c|}{ Unstandardized Coefficients } & \multirow{2}{*}{\multicolumn{2}{|c|}{$\frac{\text { Standardized Coefficients }}{\text { Beta }}$}} & \multirow[t]{2}{*}{$\mathrm{t}$} & \multirow[t]{2}{*}{ Sig. } \\
\hline & & $\mathrm{B}$ & Std. Error & & & & \\
\hline \multirow{3}{*}{1} & (Constant) & 34.396 & 1.2 & & & 28.585 & .000 \\
\hline & Work_Anxiety & -.619 & .0 & & -.613 & -15.713 & .000 \\
\hline & (Constant) & 27.929 & 1.2 & & & 22.462 & .000 \\
\hline \multirow[t]{2}{*}{2} & Work_Anxiety & -.737 & & & -.731 & -19.949 & .000 \\
\hline & Int_WA_SS & .017 & & & .378 & 10.307 & .000 \\
\hline
\end{tabular}

a. Dependent Variable: Empl_Job_Satisfaction 
In the effect of Work anxiety on the employee job satisfaction overall $(\mathrm{P}=0.000, \beta=-.619)$ that shows work anxiety has negative effect on employees job satisfaction. But while Int_WA_SS $(\mathrm{P}=0.000, \beta=+.017)$ its means while employees have social support its positive effect on their satisfaction level. Whenever the employees have good social support its effect on their reduction of anxiety and in their satisfaction level.

Table summary

\begin{tabular}{|l|r|r|r|r|}
\hline Model & R & R Square & Adjusted R Square & Std. Error of the Estimate \\
\hline 1 & & & & \\
2 & $.659^{\mathrm{a}}$ & .734 & .683 & 5.53254 \\
& $.751^{\mathrm{b}}$ & .701 & .671 & 4.86370 \\
\hline
\end{tabular}

a. Predictors: (Constant), Work_Life_Balance

b. Predictors: (Constant), Work Life Balance, Int WLB SS

In this model summary, the value of $\overline{\mathrm{R}^{2}}$ is $(0.734, .701)$ while the value of Adjusted $\left.\mathrm{R}^{2}=0 . .683, .671\right)$.

Coefficients $^{\mathrm{a}}$

\begin{tabular}{|c|c|c|c|c|c|c|c|}
\hline \multirow[t]{2}{*}{ Model } & & \multicolumn{2}{|c|}{ Unstandardized Coefficients } & Standardized $\mathrm{Co}$ & ients & \multirow[t]{2}{*}{$\mathrm{t}$} & \multirow[t]{2}{*}{ Sig. } \\
\hline & & $\mathrm{B}$ & Std. Error & Beta & & & \\
\hline \multirow{4}{*}{1} & (Constant) & 35.030 & 1.106 & & \multirow{3}{*}{-.659} & 31.677 & .000 \\
\hline & Work_Life_Balance & -1.260 & .071 & & & -17.727 & .000 \\
\hline & (Constant) & 30.153 & 1.068 & & & 28.232 & .000 \\
\hline & Work_Life_Balance & -1.556 & .068 & & -.813 & -22.878 & .000 \\
\hline 2 & Int_WLB_SS & .032 & .003 & & .392 & 11.024 & .000 \\
\hline
\end{tabular}

a. Dependent Variable: Empl_Job_Satisfaction

In the effect of work life balance on employees job satisfaction the (values $P=0.000, \beta=-.1260$ ) that shows the work life balance has negative effect on employee job satisfaction. But in the

moderation of support Int_WLB_SS (values $P=0.000, \beta=+.032$ ) its means due to social support there is a positive relationship between them. Due to social support its effect is positive that shows while employees have social support its more better in their work life balance and their satisfaction level.

\section{Conclusion}

This study proves that there is a negative relationship between work-life balance and employee job satisfaction. And also the results prove that there is a negative relationship between work place anxiety and employee job satisfaction. Social support decreases the negative relationship between work life balance as well as work place anxiety on employee job satisfaction.

\section{Limitations of the study and further agenda for research:}

This study is cross sectional and data is conducted in just once sort- and conducted in the Pakistani organizational employees, it's a limitation of conduction in the other countries employees stress level and social support effect on it. It's also being suggested to include other factors of work stress likewise physical environment and managerial skills or competences in it. Its also be a future recommendation of being used organizational citizenship behavior as a moderation between job stress and employees job satisfaction.

\section{Recommendations:}

$>$ Top management must have to understand about the workload of their employees by keeping in mind that employees are only human - they likely have a life outside of work that can compete for their attention during the week, and the need to rest on the weekend So that they can able to manage worklife balance.

$>$ Encourage the organization to invest in training for all employees for removing the stress of employees

$>$ Help employees develop an emotional support system

$>$ Encourage the organization to invest in employee self-efficacy

$>$ Top management must develop clear connections between cause and effect

$>$ Help the organization develop clear, open communication; especially during times of significant change

$>$ Help management deal with their need for control

$>$ Give workers as much control over their jobs for removing the job stress

\section{References}

McCarthy, J. M., Trougakos, J. P., \& Cheng, B. H. (2016). Are anxious workers less productive workers? It 
depends on the quality of social exchange. Journal of Applied Psychology, 101(2), 279.

Umeadi, C. A. (2015). Effect of Social Support and HIV-Related Stigma on Depression in HIV/AIDS Patients.

Pang, sK., \& Lu, C. S. (2018). Organizational motivation, employee job satisfaction and organizational performance: An empirical study of container shipping companies in Taiwan. Maritime Business Review

Bali, A. (2015). Psychological factors affecting sports performance. International Journal of Physical Education, Sports and Health, 1(6), 92-95.

Crowder, M. J. (2017). Statistical analysis of reliability data. Routledge

Miller, R. L. (2017). SPSS for social scientists. Macmillan International Higher Education.

Locke, E. A., \& Dunnette, M. D. (1976). Handbook of industrial and organizational psychology. The nature and causes of job satisfaction, 1297-1349.

Haar, J. M., Russo, M., Suñe, A., \& Ollier-Malaterre, A. (2014). Outcomes of work-life balance on job satisfaction, life satisfaction and mental health: A study across seven cultures. Journal of Vocational Behavior, 85(3), 361-373.

Bowen, P., Edwards, P., Lingard, H., \& Cattell, K. (2014). Occupational stress and job demand, control and support factors among construction project consultants. International Journal of Project Management, 32(7), 1273-1284.

Adame-Sánchez, C., González-Cruz, T. F., \& Martínez-Fuentes, C. (2016). Do firms implement work-life balance policies to benefit their workers or themselves? Journal of Business Research, 69(11), 5519-5523.

Kivimäki, M., Pentti, J., Ferrie, J. E., Batty, G. D., Nyberg, S. T., Jokela, M., ... \& Goldberg, M. (2018). Work stress and risk of death in men and women with and without cardiometabolic disease: a multicohort study. The Lancet Diabetes \& Endocrinology.

Muschalla, B., \& Linden, M. (2014). Workplace phobia, workplace problems, and work ability among primary care patients with chronic mental disorders. The Journal of the American Board of Family Medicine, 27(4), 486-494.

Racino, J. (2006). Social support. In: G. Albrecht, Encyclopedia on Disability, 1470-1471. Thousand Oaks, CA: SAGE.

Thompson, E. R., \& Phua, F. T. (2012). A brief index of affective job satisfaction. Group \& Organization Management, 37(3), 275-307.

Kalliath, T., \& Brough, P. (2008). Work-life balance: A review of the meaning of the balance construct. Journal of management \& organization, 14(3), 323-327.

Krymis, E. (2011). Women and work-life balance: A phenomenological qualitative analysis of identity, relational style, adaptive style, and drive and motivation, and the role of faith from the narrative life-story framework.

Allisey, A. F., Noblet, A. J., Lamontagne, A. D., \& Houdmont, J. (2014). Testing a model of officer intentions to quit: the mediating effects of job stress and job satisfaction. Criminal Justice and Behavior, 41(6), 751-771.

Khalatbari, J., Ghorbanshiroudi, S., \& Firouzbakhsh, M. (2013). Correlation of job stress, job satisfaction, job motivation and burnout and feeling stress. Procedia-Social and Behavioral Sciences, 84, 860-863

Lambert, E. G., Minor, K. I., Wells, J. B., \& Hogan, N. L. (2016). Social support's relationship to correctional staff job stress, job involvement, job satisfaction, and organizational commitment. The Social Science Journal, 53(1), 22-32. 